\title{
Developing Android-Based Interactive E-Modules on Trigonometry to Enhance the Learning Motivation of Students
}

\author{
https://doi.org/10.3991/ijim.v16i02.27503 \\ Asmianto $^{(凶)}$, Mochammad Hafiizh, Desi Rahmadani, Kridha Pusawidjayanti, \\ Sapti Wahyuningsih \\ Department of Mathematics, Universitas Negeri Malang, Malang, Indonesia \\ asmianto.fmipa@um.ac.id
}

\begin{abstract}
The development of technology is growing very rapidly, then it should be used for improving many important aspects of our daily life, such as learning innovation. This study aims to develop an android-based interactive e-module on trigonometries' topic to enhance the learning motivation of students. The topic of trigonometry is chosen because it lacks to be discussed. Many android-based interactive e-modules are generally limited on numbers. The contents of this e-module consist of learning outcomes, material descriptions, learning videos, and quizzes. The method in this study is Research and Development with the ADDIE model. The ADDIE model has five stages: Analyze, Design, Development, Implementation, and Evaluation. The main key in this method is the iteration process. Before the trial, the e-module is validated by substancial experts and learning media's experts. The substancial experts gave a score 4.32 out of 5 which indicates the modules are valid substancially. The learning media's expert gave a score 4.18 out of 5 which indicates the modules are very valid. Then, this e-modules is implemented into small class and large class. The practicality and the effectiveness of this e-modules are measured. The practicality of this e-modues in the small class have score 4.18 out of 5 , while it have score 4.28 out of 5 in the large class. The effectiveness of this e-modules in small class have score 4.28 out of 5 , while it have score 4.31 out of 5 in large class. These results indicate that android-based interactive e-modules are effective and recommended to be used in teaching-learning process on trigonometry.
\end{abstract}

Keywords — android-based interactive e-modules, trigonometry, learning motivation

\section{$1 \quad$ Introduction}

Mathematics plays an important role in the development of science and technology [1]. One of the interesting topics in mathematics is trigonometrics. During the covid-19 pandemic, most of the activities were conducted online, as well as lectures at Universitas Negeri Malang, Indonesia. The lecturers have to adapt to this situation. The students will be bored if the teaching materials for online learning are not interactive and not interesting. As a result, the students will find difficulties during online. 
An electronic teaching material or better known as an e-module must be interactive with the user (students) so that they can learn independently and pleasantly. This is in accordance with [2] which says that a good module is one that is able to make the learning process more interesting, more interactive, convey historical messages through images and videos, encourage learning through instrumentals, develop auditive senses that are conveyed more easily understood. Android is one of the operating systems that can be found on smartphones and tablets [3]. There are several advantages of Android [4], among others: a complete platform, open-source, and free platform. The advantages of this android provide a great opportunity for programmers to be involved in developing and creating Android applications. Learning math using a tablet has better results than using a PC or laptop [5]. Learning using smartphones and learning through games are two important elements in improving learning technology [6]. Today, most children's lives cannot be separated from the digital interactive media of the smartphone so game-based math learning is very feasible and meaningful [7]. The tendency of students to use media as a media of learning will significantly determine the success of learning [8]. The design of a well-organized media can have a positive influence on students [9]. By using the smartphone applications in learning, teachers have a very good perception. Well-designed applications will assist students in developing math skills [10]. The appropriate use of learning technologies will support the implementation of learning [11]. Research on learning using Android and iOS-based apps, as stated in [12]-[16], yielded excellent results. One of the advantages of using computer technology in learning is that students' cognitive abilities can develop further. In addition, the use of computers and tablets during learning can improve students' ability to understand numbers [18], math literacy [19], students' cognitive, and affective abilities [20], [21]. This research shows that computer-based integrated training can enhance students' creativity [22]. In addition, computer-based learning also improves positive outcomes in problem solving, procedural knowledge, and conceptual knowledge [23]. Physically active learning can be beneficial for students in learning mathematics [24]. These results are in line with previous research stating that technology-based learning media has a positive impact on students and assists them in studying mathematics. [25], [26]. Therefore, android-based interactive e-modules are needed to be developed in online learning during the covid-19 pandemic.

\section{Literature review}

\subsection{Trigonometry}

Trigonometry is one of the basic and mandatory courses in the program study S1 Mathematics and S1 Mathematics Education at Malang State University. Trigonometry is described as one of the most basic mathematical topics that will later play an important role in the study of algebra, geometry, and graphic reasoning [27]. Studying trigonometric theorems and concepts is needed to improve students' skills in analyzing, able to think creatively and logically [28]. 


\subsection{Android-based mobile learning}

Mobile learning is one of the answers to education reform [29]. Mobile learning helps students in creating social interactions. It leads to collaborative, interactive learning, and direct feedback as well as collaboration between peers. It can also improve the structure of knowledge, performance, and learning motivation [30]. Recently, the smartphone used by most Indonesian's students is Android as its operating system. Android smartphones are very affordable because they can be purchased by almost anyone as a means to communicate [31]. In addition, Android is also the most popular mobile operating system on the market [32].

\section{Research method}

\subsection{Research design}

The method used in this study is Research and Development with the ADDIE model. The ADDIE model has five stages: Analyze, Design, Development, Implementation, and Evaluation. The main key in this method is the iteration process.

\subsection{Research subject}

This research was conducted in the department of mathematics Universitas Negeri Malang, Indonesia. The subjects in this study are mathematics lecturers, substantial experts, learning media's experts, and students. Sixty-three students participated in the trial which divided by 9 students participated in small trial class and 54 students participated in large trial class. Students in each class have various abilities in mathematics including students with high ability, students with moderate abilities, and students with low abilities. The aim of this study involving students with diverse abilities is to be able to identify the impact of android-based modules on all students with high, moderate or low abilities.

\subsection{Data collection instrument}

The data in the study was obtained using several techniques including interviews, questionnaires, and tests. Students are given questionnaires to fill out after they have already conducted a trial, both in small trial class and large trial class. The question on the questionnaire consists of two aspects, namely the practicality aspect and the effectiveness aspect. In terms of practicality, the indicators are as follows: ease use of the android-based module; clarity of the instruction of how to use, Ease interactions during learning through available menus; and the appeal of the display and animation. Meanwhile, the indicators of its effectiveness are as follows: the description of mathematical contents and videos that can help students understand the concept of trigonometry; the language used in the material is easy to understand. And the android-based modules that can make learning trigonometry more enjoyable. 


\subsection{Data analysis}

In this study, quantitative data is obtained through validation sheets and student questionnaires. The analysis is then conducted using descriptive statistics. On the other hand, qualitative data in the form of comments, student suggestions, and work are used for discussion in e-module revision. The measurement's instrument in this study uses the Likert scale which used to measure a person's attitudes, opinions, and perceptions or groups about an event. Here is a table of the category, the related score of each category, and how to relate the average score to the given category obtained from the substancial experts, the learning media's experts, and student feedback [33], [34].

Table 1. Likert scale for assessment

\begin{tabular}{|l|c|c|}
\hline \multicolumn{1}{|c|}{$\begin{array}{c}\text { Category } \\
\text { (Alternative Answers) }\end{array}$} & $\begin{array}{c}\text { Related } \\
\text { Score }\end{array}$ & $\begin{array}{c}\text { How to relate the average score }(\boldsymbol{X}) \\
\text { to the given category }\end{array}$ \\
\hline Very Good/Very Valid & 5 & $X>4.21$ \\
\hline Good/Valid & 4 & $3.40<X \leq 4.21$ \\
\hline Acceptable & 3 & $2.60<X \leq 3.40$ \\
\hline Poor/Less Valid & 2 & $1.79<X \leq 2.60$ \\
\hline Very Poor/Invalid & 1 & $X \leq 1.79$ \\
\hline
\end{tabular}

With the eligibility category in the table above, the recapitulation of validation data can be concluded based on the specified category.

\section{$4 \quad$ Results and discussion}

This research was conducted using the ADDIE model. In this model the concept used is an iteration process that considers various aspects that affect to get the best results. The ADDIE model has five stages: Analyze, Design, Development, Implementation, and Evaluation. Here's an explanation for each stage.

\subsection{Analysis}

In this stage, several related observations were made, including learning environment, audience, problems to be solved, expectations to be achieved, and what can make students more passionate about learning. In this stage, the results shows that mathematics' students majors need a learning media that is easy to use, interesting and effective. The interview results showed that students and lecturers revealed that trigonometric lessons were considered monotonous, less interesting and the material difficult to understand. This causes students to get bored quickly and lack passion for learning. Moreover, some students live in areas whose networks are not good, so it is important to make learning innovations that can not only be accessed online but can also be accessed offline.

\subsection{Design}

The design of android-based interactive e-module is developed based on previous analysis at section 4.1. This design includes setting learning goals, creating online content, 
developing scripts, selecting user interfaces and environments, and selecting assessment methods. In this e-module, the main menu consists of learning objectives, learning materials or contents, e-learning videos, and assessments or quizzes. In the designing process, the lay out uses PowerPoint and the interactive quizzes are build using the i-spring suite.

\subsection{Development}

The next stage is development, we organize and implement what has been done in the previous stage. At this stage, the team discusses which parts will be developed to get the best results. Here we start creating course content on our products in the form of audio, video, animation, quizzes, instructional guides, and course-related matters. In addition, the selection of font size, font type, background color, and appearance in our products is also done at this stage. Here are some android-based interactive e-module displays that have been developed.

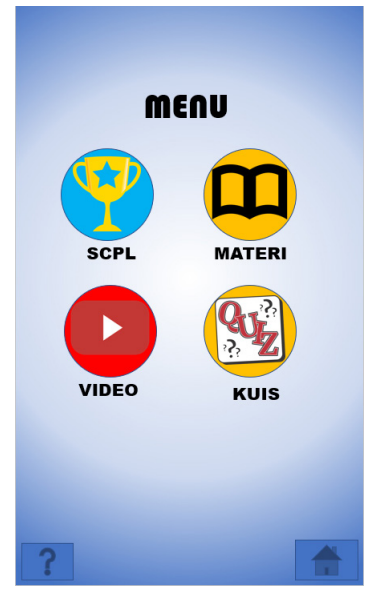

Fig. 1. Menu

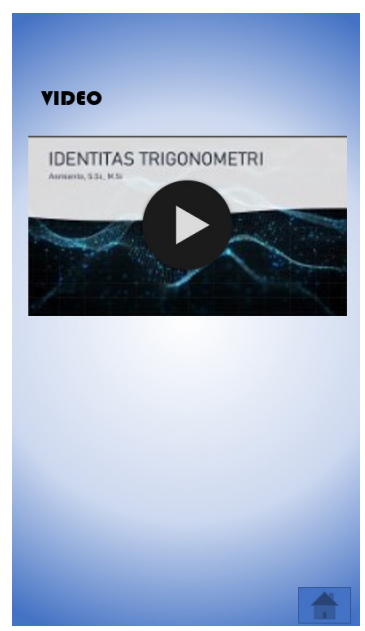

Fig. 3. E-learning video

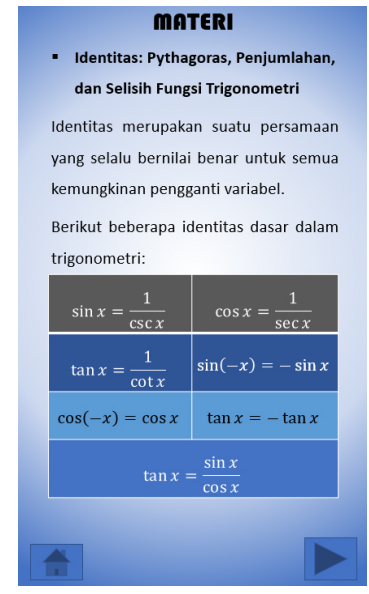

Fig. 2. Content

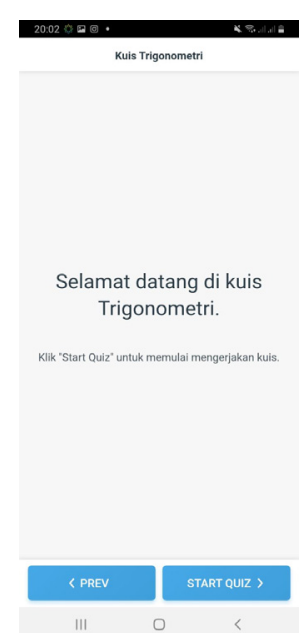

Fig. 4. Quizzes 
The videos in this e-module can be opened only by using the internet, because this video is made in sync with Youtube. This will make the application is lighter to use and the video size is smaller than when the video uploaded in the application directly. If students want the video in the offline form then they can download it, so that the video can be played without the internet.
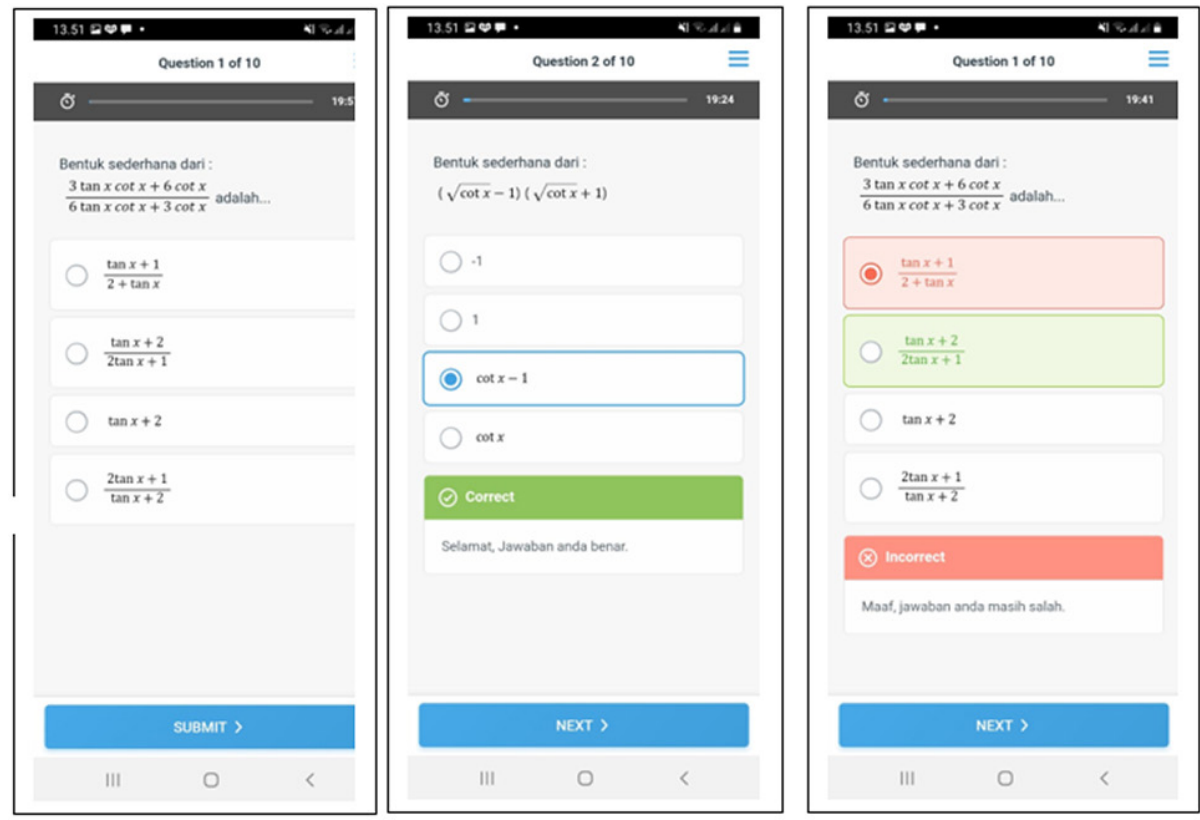

Fig. 5. More quizzes view

In Figure 5, when students answer the right-wrong questions, the students (users) know the correct answer immediately. There are feedback "congratulations, your answer is right" for the right answer, and "Sorry, your answer is still wrong" to the student's answer that is incorrect. The score of quizzes will be sent to the email of the question maker or lecturer, so that lecturers can directly know the score of quizzes of each student without manually correction. The lecturers are able to know the students' abilities and understanding of this material. Before being implemented on students, validation is carried out from learning media's experts and substancial experts. The scores of validation are presented in Table 2 . 
Table 2. Validation scores

\begin{tabular}{|c|c|}
\hline Indicator & Average Score \\
\hline \multicolumn{2}{|l|}{ Substancial Experts } \\
\hline The mathematical contents are easy to understand & 4.41 \\
\hline The mathematical contents are suitable for the intended learning outcomes & 4.30 \\
\hline It motivates students & 4.25 \\
\hline Average score & 4.32 \\
\hline \multicolumn{2}{|l|}{ Learning Media's Expert } \\
\hline Easy to use & 4.30 \\
\hline High Accessibility & 4.19 \\
\hline Attractive media & 4.20 \\
\hline Suitable Animation & 4.03 \\
\hline Average score & 4.18 \\
\hline
\end{tabular}

Table 2 shows that validation scores from substancial experts and learning media's experts are 4.32 and 4.18 out of 5 . Based on Table 1 the following results were categorized as valid so that modules could be used on students. However, modules still need a few revisions based on the advice from substancial experts and learning media's experts. Some suggestions from the experts including: a little part of animation needs to be developed, colors needs to be brighter and transparency, and the visual illustrations are needed in some parts of the material so that students are easier to understand.

\subsection{Implementation}

The e-modules are revised based on the suggestions from the experts. It is then tested on mathematics' students at Universitas Negeri Malang. Sixty-three students participated in the trial. 9 students participated in the small trial class and 54 students of the first year mathematics departmen participated in the large trial class. Students in each class have various abilities in mathematics including students with high ability, students with moderate abilities, and students with low abilities. The aim of this study involving students with diverse abilities is to be able to identify the impact of androidbased modules on all students with high, moderate or low abilities. After students conducts trial, they are given questionnaires related to the assessment of the e-module. The practicality and effectiveness test results of small trial class and large trial class are given in Table 3. 
Table 3. Data of student's responses questionnaire result

\begin{tabular}{|l|c|c|}
\hline \multicolumn{1}{|c|}{ Indicator } & $\begin{array}{c}\text { Average Score of } \\
\text { Small Trial Class }\end{array}$ & $\begin{array}{c}\text { Average Score of } \\
\text { Large Trial Class }\end{array}$ \\
\hline \multicolumn{1}{|c|}{ Practically Aspect } \\
\hline The materials are easy to understand & 4.22 & 4.3 \\
\hline The materials allow students to interact and learn math & 4.28 & 4.25 \\
\hline It facilitates understanding & 4.12 & 4.35 \\
\hline $\begin{array}{l}\text { The use of images and animation in learning media is } \\
\text { attractive }\end{array}$ & 4.08 & 4.40 \\
\hline Average practically scores & $\mathbf{4 . 1 8}$ & $\mathbf{4 . 2 8}$ \\
\hline \multicolumn{2}{|c|}{ Effectiveness Aspects } \\
\hline It motivates students & 4.12 & 4.20 \\
\hline The materials make students love mathematics & 4.50 & 4.50 \\
\hline Students can understand trigonometry concepts & 4.23 & 4.23 \\
\hline It makes students want to understand trigonometry further & 4.25 & 4.30 \\
\hline Average effectiveness scores & $\mathbf{4 . 2 8}$ & $\mathbf{4 . 3 1}$ \\
\hline
\end{tabular}

Table 3 shows that the average test scores of practicalities and effectiveness in large trial class are 4.28 and 4.31, respectively. Based on Table 1, these results are classified to a very good category. Students also provide positive comments and suggestions after the trials, such as, "I want to learn more", "Interesting application", "If the display is beautified then the application will be more interesting", and "I love mathematics". At this stage, we not only focus on the feedback of students but also see if the method is good enough or not and whether learning outcomes can be achieved or not. The results show that the methods used are effective and students can achieve learning outcomes. However, there are some notes and expectations from both substancial experts, learning media's experts, and students related to the module development.

\subsection{Evaluation}

The last stage in the ADDIE method is evaluation. At this stage that we respond and improve the e-modules based on the suggestion and feedback from experts and the students. Based on the results of the trial test of android-based interactive e-module products above as a whole get valid categorization, both from media experts, material experts and students. This suggests that the android-based interactive e-modules can be very likely implemented on teaching-learning process. One of the main objectives of integrating between technology and learning media are to solve the problem of lack of interactive media in learning activities [35]. The results of this study are relevant to the findings of previous studies, where the use of applications in learning provides many benefits. These include facilitating learning to read the Qur'an, improving students' speaking skills and increasing students' learning motivation for science subjects [36] [37] [38]. 


\section{Conclusion}

Based on the validation results by learning media's experts, substancial experts, and lecturers which teach the course of trigonometry, as well as students' responses, it can be concluded that the developing android-based interactive e-module on trigonometry has been categorized as very good or very valid and deserves to be used as a learning media in lectures the topic of trigonometry.

\section{Acknowledgement}

The authors would like to thank the PNBP UM for funding this research in 2021 fiscal year.

\section{$7 \quad$ References}

[1] A. Rionaldy and K. Ika. 2020. "Development Of Android-Based Edu-Games For Pythagorean Theorem". Jurnal Ilmiah Pendidikan Matematika, vol. 9, no. 2, 339-345.

[2] V. F. M. Yuniarti, N. Anriani, and C. A. H. F. dan Santosa (2020). Pengembangan E-modul Berbasis Smartphone Pada Materi Integral Tak Tentu Berorientasi Keterampilan Abad Ke-21. Jurnal Riset Teknologi dan Inovasi Pendidikan (JARTIKA). https://journal-litbang-rekarta.co.id/index.php/jartika, vol. 3 no. 2, Hal 222-233. https://doi.org/10.36765/ jartika.v3i2.253

[3] Satyaputra, Alfa dan Aritonang, Eva Maulina. 2014. Beginning Android Programming with ADT Bundle. Jakarta: Elex Media Kompuindo.

[4] Zuliana dan Nasution, Muhammad Irwan Padli. 2013. "Aplikasi Pusat Panggilan Tindakan Kriminal Di Kota Medan Berbasis Android”. Makalah disajikan dalam Seminar Nasional Informatika SNIf2013: Swarm Intelligent System, Yogyakarta, 7 September.

[5] S. Papadakis, M. Kalogiannakis, and N. Zaranis, "Comparing Tablets and PCs in teaching Mathematics: An attempt to improve Mathematics Competence in Early Childhood Education," Presch. Prim. Educ., vol. 4, no. 2, p. 241, 2016. https://doi.org/10.12681/ppej.8779

[6] L. Bennis, and S. Amali, "From learning game to adaptive ubiquitous game-based learning," Int. J. Emerg. Technol. Learn., vol. 14, no. 16, pp. 55-65, 2019. https://doi.org/10.3991/ijet. v14i16.10701

[7] E. A. Wartella et al., Digital media use by young children: Learning, effects, and health outcomes. Elsevier Inc., 2018. https://doi.org/10.1016/B978-0-323-54854-0.00016-3

[8] J. P. Byrnes, and B. A. Wasik, "Factors predictive of mathematics achievement in kindergarten, first and third grades: An opportunity-propensity analysis," Contemp. Educ. Psychol.,vol. 34, no. 2, pp. 167-183, 2009. https://doi.org/10.1016/j.cedpsych.2009.01.002

[9] D. L. G. Borzekowski, "A quasi-experiment examining the impact of educational cartoons on Tanzanian children,” J. Appl. Dev. Psychol., vol. 54, no. March 2017, pp. 53-59, 2018. https://doi.org/10.1016/j.appdev.2017.11.007

[10] M. A. Abugohar, K. Yunus, and R. A. Rashid, "Smartphone applications as a teaching technique for enhancing tertiary learners' speaking skills: Perceptions and practices," Int. J. Emerg. Technol. Learn., vol. 14, no. 9, pp. 74-92, 2019. https://doi.org/10.3991/ijet. $\underline{\text { v14i09.10375 }}$ 
[11] A. W. McCulloch, K. Hollebrands, H. Lee, T. Harrison, and A. Mutlu, "Factors that influence secondary mathematics teachers' integration of technology in mathematics lessons," Comput. Educ., 2018. https://doi.org/10.1016/j.compedu.2018.04.008

[12] M. Murdiono, Suyato, E. N. Rahmawati, and M. A. Aziz, "Developing an android-based mobile application for civic education learning,” Int. J. Interact. Mob. Technol., vol. 14, no. 16, pp. 180-193, 2020. https://doi.org/10.3991/ijim.v14i16.14967

[13] A. Huda, N. Azhar, Almasri, K. Anshari, and S. Hartanto, "Practicality and effectiveness test of graphic design learning media based on android," Int. J. Inter-act. Mob. Technol., vol. 14, no. 4, pp. 192-203, 2020. https://doi.org/10.3991/ijim.v14i04.12737

[14] M. Friedl, M. Ebner, and M. Ebner, "Mobile Learning Applications for An-droid und iOS for German Language Acquisition based on Learning Analytics Measurements," Int. J. Learn. Anal. Artif. Intell. Educ., vol. 2, no. 1, p. 4, 2020. https://doi.org/10.3991/ijai.v2i1.12317

[15] S. Papadakis, M. Kalogiannakis, and N. Zaranis, "Educational apps from the Android Google Play for Greek preschoolers: A systematic review," Comput. Educ., vol. 116, pp. 139160, 2018. https://doi.org/10.1016/j.compedu.2017.09.007

[16] A. C. Sari, A. M. Fadillah, J. Jonathan, and M. R. D. Prabowo, "Interactive gamification learning media application for blind children using android smartphone in Indonesia," Procedia Comput. Sci., vol. 157, pp. 589-595, 2019. https://doi.org/10.1016/j.procs.2019.09.018

[17] S. M. M. de Mooij, N. Z. Kirkham, M. E. J. Raijmakers, H. L. J. van der Maas, and I. Dumontheil, "Should online math learning environments be tailored to individuals' cognitive profiles?” J. Exp. Child Psychol., vol. 191, p. 104730, 2020. https://doi.org/10.1016/j. jecp.2019.104730

[18] S. Papadakis, M. Kalogiannakis, and N. Zaranis, "The effectiveness of computer and tablet assisted intervention in early childhood students' understanding of numbers. An empirical study conducted in Greece,” Educ. Inf. Technol., vol. 23, no. 5, pp. 1849-1871, 2018. https://doi.org/10.1007/s10639-018-9693-7

[19] P. Dorouka, S. Papadakis, and M. Kalogiannakis, "Tablets and apps for promoting robotics, mathematics, STEM education and literacy in early childhood education," Int. J. Mob. Learn. Organ., vol. 14, no. 2, pp. 255-274, 2020. https://doi.org/10.1504/IJMLO.2020.106179

[20] H. Jeong, C. E. Hmelo-Silver, and K. Jo, "Ten years of Computer-Supported Collaborative Learning: A meta-analysis of CSCL in STEM education during 2005-2014," Educ. Res. Rev., vol. 28, no. June, p. 100284, 2019. https://doi.org/10.1016/j.edurev.2019.100284

[21] W. Kozakowski, "Moving the classroom to the computer lab: Can online learning with inperson support improve outcomes in community colleges?" Econ. Educ. Rev., vol. 70, no. March, pp. 159-172, 2019. https://doi.org/10.1016/j.econedurev.2019.03.004

[22] Y. chu Yeh, E. M. Rega, and S. Y. Chen, "Enhancing creativity through aesthetics-integrated computer-based training: The effectiveness of a FACE approach and exploration of moderators," Comput. Educ., vol. 139, no. 64, pp. 48-64, 2019. https://doi.org/10.1016/j. compedu.2019.05.007

[23] M. Volk, M. Cotič, M. Zajc, and A. Istenic Starcic, "Tablet-based cross-curricular maths vs. traditional maths classroom practice for higher-order learning outcomes," Comput. Educ., vol. 114, pp. 1-23, 2017. https://doi.org/10.1016/j.compedu.2017.06.004

[24] M. Vetter, H. T. O'Connor, N. O'Dwyer, J. Chau, and R. Orr, "Maths on the move': Effectiveness of physically-active lessons for learning maths and increasing physical activity in primary school students," J. Sci. Med. Sport, 2020. https://doi.org/10.1016/j. jsams.2019.12.019

[25] J. Hamari, D. J. Shernoff, E. Rowe, B. Coller, J. Asbell-Clarke, and T. Ed-wards, "Challenging games help students learn: An empirical study on engagement, flow and immersion in game-based learning," Comput. Human Behav., 2016. https://doi.org/10.1016/j. chb.2015.07.045 
[26] A. Qohar, Susiswo, S. H. Nasution, and S. Wahyuningsih, "Development of Android-Based Mathematics Learning Game on the Topic of Congruence and Similarity," Int. J. Interact. Mob. Technol., vol. 15, no. 9, pp. 52-69, 2021. https://doi.org/10.3991/ijim.v15i09.20723

[27] Weber, K. (2005). Students' understanding of trigonometric functions. Mathematics Education Research Journal, vol. 17, no. 3, 91-112. https://doi.org/10.1007/BF03217423

[28] Dündar, S. (2015). Mathematics teacher-candidates' performance in solving problems with different representation styles: The trigonometry example. EURASIA Journal of Mathematics, Science and Technology Education, vol. 11, no. 6, 1379-1397. https://doi.org/10.12973/ eurasia.2015.1396a

[29] S. Jelatu, Y. Kurniawan, V. S. Kurnila, K. Mandur, and R. Jundu, "Collaboration TPS Learning Model and m-Learning Based on Android for Understanding of Trigonometry Concepts with Different Cognitive Style" International Journal of Instruction, October 2019. vol. 12, no. 4, https://doi.org/10.29333/iji.2019.12435a

[30] Mouza, C., and Barrett-Greenly, T. (2015). Bridging the app gap: An examination of a professional development initiative on mobile learning in urban schools. Computers and Education. vol. 88, 1-15. https://doi.org/10.1016/j.compedu.2015.04.009

[31] Gunawan, A. A., Hartanto, B., Mili, A., Budiharto, W., Salman, A. G., \& Chandra, N. (2017). Development of affordable and powerful swarm mobile robot based on smartphone, android and IOIO board. Procedia Computer Science, vol. 116, 342-350.

[32] Meiliana, Septian, I., Alianto, R. S., \& Daniel. (2018). Comparison analysis of android GUI testing frameworks by using an experimental study. Procedia Computer Science, vol. 35, 736-748. https://doi.org/10.1016/j.procs.2018.08.211

[33] S. Kurt, "ADDIE Model : Instructional Design," in Educational Technology, August 29, 2017.

[34] Sukarjo. (2006). Kumpulan materi evaluasi pembelajaran (Jurusan Teknologi PembelajaranProgram Pascasarjana Universitas Negeri Yogyakarta)

[35] Darmaji, D. A. Kurniawan, Astalini, A. Lumbantoruan, and S. C. Samosir, "Mobile learning in higher education for the industrial revolution 4.0: Perception and response of physics practicum,” Int. J. Interact. Mob. Technol., vol. 13, no. 9, pp. 4-20, 2019. https://doi. org/10.3991/ijim.v13i09.10948

[36] Y. Hanafi, H. J. Hendrawan, and I. N. Hakim, “Accelerating Qurán Reading Fluency through Learning Using QURÁNI Application for Students with Hearing Impairments," International Journal of Emerging Technologies in Learning (iJET), vol. 14, no. 6, pp. 110-132, 2019. https://doi.org/10.3991/ijet.v14i06.9863

[37] M. A. Abugohar, K. Yunus, and R. Ab Rashid, "Smartphone applications as a teaching technique for enhancing tertiary learners' speaking skills: Perceptions and Practices" International Journal of Emerging Technologies in Learning (iJET), vol. 14, no. 9, pp. 74-92, 2019. https://doi.org/10.3991/ijet.v14i09.10375

[38] C. Hursen and C. Bas, "Use of gamification applications in Science Education," International Journal of Emerging Technologies in Learning (iJET), vol. 14, no. 1, pp. 4-23, 2019. https://doi.org/10.3991/ijet.v14i01.8894

\section{Authors}

Asmianto is a lecturer at Department of Mathematics, Universitas Negeri Malang, Indonesia. His research interests include mathematics education; IT based learning, and applied mathematics. Email: asmianto.fmipa@um.ac.id 
Mochammad Hafizh is a lecturer at Department of Mathematics, Universitas Negeri Malang, Indonesia. His research interests are mathematics education, including IT-based learning, HOTS for students, and curriculum development, and mathematics, including partial differential equations, mathematical modelling, and convolutional neural network. Email: moch.hafiish.fmipa@um.ac.id

Desi Rahmadani is a lecturer at Department of Mathematics, Universitas Negeri Malang. Her research interests include Graph Theory, Algebra, Applied Mathematics and mathematics education. Email: desi.rahmadani.fmipa@um.ac.id

Kridha Pusawidjayanti is a lecturer at Department of Mathematics, Universitas Negeri Malang, Indonesia. Her research interests include applied mathematics, dinamical analysis and mathematics education. Email: kridha.pusawidjayanti.fmipa@, um.ac.id

Sapti Wahyuningsih is an associate professor at Department of Mathematics, Universitas Negeri Malang, Indonesia. Her research interests include applied mathematics and disruptive learning innovations in higher education. Email: sapti.wahyuningsih. fmipa@um.ac.id

Article submitted 2021-10-12. Resubmitted 2021-11-08. Final acceptance 2021-11-08. Final version published as submitted by the authors. 